\title{
İznik Meslek Yüksekokulu Turist Rehberliği Bölümü Öğrencilerinin COVID-19 Nedeni ile Uzaktan Yapılan Eğitime Bakış Açıları
}

\author{
Attitudes of Tourist Guidance Students towards the Distance Education due to \\ the COVID-19
}

\section{Ayşen ACUN KÖKSALANLAR ${ }^{1}$, Füsun ESENKAL ÇÖZELİ ${ }^{2}$}

\begin{abstract}
Öz
Amaç: $\mathrm{Bu}$ çalışmanın amacı İznik meslek yüksekokulu turist rehberliği bölümünde öğrenim gören öğrencilerin uzaktan eğitime yönelik bakıș açılarının belirlenmesidir.

Tasarım/Yöntem: Saha araştırmasında yöntem olarak yarı yapılandırılmış mülakat tekniği ve tesadüfi olmayan örneklem yöntemi kullanılmıştır. Görüşmeler sonrası formlardan elde edilen veriler içerik analizine tabi tutulmuştur.

Bulgular: Yapılan içerik analizi sonucunda öğrencilerin \%52'sinin uzaktan eğitimi olumsuz olarak değerlendirdikleri belirlenmiştir. Öğrencilerin, birebir eğitim ve sınıf ortamının olmaması, iletişim kurulamaması, internet sorunları, bilgisayar gibi teknik araç eksikliği gibi nedenlerle uzaktan eğitimi olumsuz olarak değerlendirdikleri belirlenmiștir. Turist rehberliği öğrencilerinin ders çalışmaya isteksiz oldukları, odaklanamadıkları, derslerden ve okuldan uzaklaştıkları da çalışma sonucunda tespit edilmiștir. Öğrencilerin \%6'sı rahat ve konforlu bir ortam olması, kolay, ulaşılabilir ve zamanın etkin kullanılması gibi nedenlerden dolayı uzaktan eğitimi olumlu olarak değerlendirmișlerdir.
\end{abstract}

Sınırlılıklar: Örneklemin sadece İznik MYO turist rehberliği ögrencilerinden oluşması ve pandemi nedeniyle saha araștırmasının online yapılması araştırmanın sınırlılığıdır.

Özgünlük/Değer: Çalışma COVID-19 Pandemi sürecinde, uzaktan eğitimde yaşanan firsat ve sıkıntıların neler olduğunun saptanması ve bu yönde gerekli olan çalışmaların yapılması açısından önem arz etmektedir. Yapılan yazın taramasında bu doğrultuda yapılan kısıtlı çalışmaya rastlanmıştır.

Anahtar Kelimeler: Uzaktan Eğitim, Turist Rehberliği Öğrencileri, COVID-19

\begin{abstract}
Purpose: This study aims to determine the opinions of tourist guidance students, who are used to formal education, about distance education.

Design/Methodology: Semi-structured interview method and nonrandom sampling method were used in the study. The data obtained from the forms after the interviews were subjected to content analysis.

Findings: As a result of the content analysis, it was seen that $52 \%$ of the students evaluated distance education negatively. Examining the reasons why they were evaluated negatively, these reasons have been found to be: lack of face-to-face or one-to-one education and/or classroom environment, technical troubles such as internet and connection and/or lack of technical equipment such as computer, failure to make contact with, and failure to understand and to learn the lecture. The students stated that they were unwilling to study and always procrastinated their studies, could not focus on the lectures, could not use their time well and that they digressed from both lectures and school. Only $6 \%$ of the participants evaluated the distance education process positively. The students defined distance education as a system that offers a comfortable environment is easily accessible and allows much more effective use of time.

Limitations: The limitation of the study is that the sample consists of only İznik Vocational School tourist guidance students and online field research due to the pandemic.

Originality/Value: The study is important in terms of determining the opportunities and difficulties experienced in distance education during the COVID-19 Pandemic process and making improvements in this direction. A limited number of studies in this direction were found in the literature review.

Keywords: Distance Education, Tourist Guidance Students, COVID-19
\end{abstract}

\footnotetext{
1 Öğr. Gör. Dr, Uludağ Üniversitesi, İznik MYO, Seyahat Turizm ve Eğlence Hizmetleri Bölümü, Turist Rehberliği Program1, aysenacun@uludag.edu.tr, ORCID: 0000-0002-9551-0702

2 Dr. Öğr. Üyesi, Bandırma 17 Eylül Üniversitesi, Erdek MYO, Yönetim ve Organizasyon Bölümü, Sağlık Turizmi İşletmeciliği Programı, fcozeli@bandirma.edu.tr, ORCID: 0000-0002-9402-1640
} 


\section{GİRIS}

Tarih içinde eğitimin rolüne bakıldığında toplumların gelişmesinde oldukça önemli rol oynadığı görülmektedir. Yaşanılan dönem içerisinde eğitim ve öğrenim ile ilgili çalışmalar hep devam etmiştir. Günümüz dünyasında ortaya çıkan teknolojik gelişmeler eğitim konusunda yeni kavramların ortaya çıkmasına neden olmuştur. Gelişen teknoloji pek çok alanda kullanıldığı gibi eğitim alanında da kullanılmakta ve eğitimin yeniden düzenlenmesine neden olmaktadır (Ekici, 2003; Al \& Madran, 2004; Çoban, 2013). Hayata uyum sağlayabilmek için de toplumların eğitime olan ihtiyaçları gün geçtikçe artmıştır (Birişçi, 2013). Çünkü insan gücü yetiştirmenin tek yolu eğitim ve öğretimdir. Eğitim hayatın bütününü oluşturmakta olup yalnızca hayatı öğreten bir kavram değildir (Deperlioğlu \& Yıldırım, 2009). Eğitimin bu kadar önemli rol oynadığı ve teknolojik imkanların daha fazla olduğu günümüzde eğitime COVID-19 pandemisi nedeni ile önce ara verilmiş daha sonra ise uzaktan yapılmasına karar verilmiştir. Bursa Uludağ Üniversitesi İznik MYO normal şartlarda örgün eğitim veren bir kurumdur. Fakat COVID-19 pandemisi nedeni ile uzaktan eğitime geçmek zorunda kalmıştır. Bursa Uludağ Üniversitesi İznik Meslek Yüksekokulunda 2019-2020 bahar yarıyılında dersler sisteme pdf formatındaki ders dosyaları yüklenerek ve ödev verilerek gerçekleştirilmiştir. Bunun dışında yapılan final sınavları da sistem üzerinden yapılmıştır. COVID-19 pandemisi nedeniyle uzaktan eğitime geçen turist rehberliği öğrencilerinin uzaktan eğitime bakış açılarının olumlu mu yoksa olumsuz mu olduğunun belirlenmesi araştırmanın problemini oluşturmaktadır. $\mathrm{Bu}$ çalışmada örgün eğitime alışkın olan turist rehberliği öğrencilerinin uzaktan eğitim hakkındaki düşüncelerinin belirlenmesi amaçlanmıştır. Bu amaç doğrultusunda öncelikle uzaktan eğitim hakkında literatür taraması yapılmıştır.

Dünyada ilk uzaktan eğitim uygulaması 1840 yılında Isaac Pitman tarafindan mektupla uzaktan eğitim yöntemiyle başlamıştır. Isaac Pitman mektupla stenografi eğitimi vermiştir. Almanya'da 1856 yılında kurulan dil okulu ilk örgütlü uzaktan eğitim hizmeti olarak tarihe geçmiştir. 1870'li yıllara gelindiğinde Illinois Wesleyan Üniversitesi lisans ve yüksek lisans alanlarında evde öğrenim programı başlatmıştır. 1914'te ABD'de uzaktan eğitimin yaygınlaştırılmasını sağlayan bir yasa çıkarılmıştır (Ağır, 2007; Düzakın \&Yalçınkaya, 2008: 230; Erturgut, 2008; Toker Gökçe, 2008; Horzum vd., 2013; Kırık, 2014: 80). Türkiye'de ise uzaktan eğitim ile ilgili ilk çalışmalar 1924 yılında gündem olmuştur. İlk gündem olduğu tarihten 1960'lı yıllara kadar uzaktan eğitim kavramı öncelikle kavramsal olarak tartışılmış ve uzaktan eğitim uygulamaları ile ilgili temeller atılmışıı. 1960 yılında Mektupla Öğretim Merkezi adında bir kurul oluşturulurken 1970'li y1llarda uzaktan eğitim ile ilgili farklı alanlarda çalışmalara devam edilmiştir. 1980 yılında Anadolu Üniversitesi Açık Öğretim Fakültesi kurularak uzaktan eğitim yükseköğretim için de yapılmaya başlanmıştır. 1990'lı y1llardan sonra uzaktan eğitim hem ilköğretim hem de yükseköğretim düzeyinde gelişmiş ve birçok öğrenciyi içinde barındıran bir sistem olmuştur. 2000'li yılların başından sonra bilgi ve iletişim teknolojileri alanında önemli gelişmeler yaşanmıştır. Bu gelişmeler sayesinde uzaktan eğitim daha ulaşılabilir hale gelmiş, eğitim firsatları artmış ve milyonlarca öğrenciye hitap etmeye başlamıştır (Akdemir 2011: 69; Demir, 2014; Özbay, 2015; Bozkurt, 2017). Hem artan öğrenci sayısı hem de hayat koşullarının kişileri sürekli kendilerini yenilemek zorunda bırakması nedeniyle uzaktan eğitim alternatif bir eğitim modeli olarak ortaya çıkmıştır (Ateş \& Altun, 2008). Literatürde uzaktan eğitime yönelik çeşitli tanımlar mevcuttur;

İşman (2011) uzaktan eğitimi; “öğretmen ve ögrencinin aynı mekânlarda bulunmak zorunda olmadı̆̆ ve ĕgitim-ögretim faaliyetlerinin posta hizmetleri ve bilgi iletişim teknolojileri sayesinde yürütülen bir eğitim sistemi modelidir" șeklinde tanımlamıştır. "Uzaktan eğitim zaman ve yerden bağımsız, bireyselleştirilmiş eğitim imkânı sağlayan ve günümüzde artık iletişim teknolojileri ve özellikle de internet aracılığılyla gerçekleştirilen en çă̆daş eğitim biçimidir" (Baturay \& Bay, 2009). "Eğitici ve ögrrenenin farkl yerlerde olduğu, istenilen zamanda ögrrenme ve ögretme faaliyetlerinin bilgi ve iletişim teknolojileri aracıllğglyla gerçekleştiği bir sistem olarak nitelendirilir" (Fidan, 2016). "Uzaktan eğitim, geleneksel ĕgitim-ögretim yöntemlerindeki sinırlllıklar nedeniyle sinıf içi etkinliklerin yürütülemediği durumlarda, eğitim çalışmalarını planlayanlar ve uygulayanlar ile ögrenenler arasında, iletişim ve etkileşimin özel olarak hazırlanmış ögretim üniteleri ve çeşitli ortamlar yoluyla belli bir merkezden sağlandı̆̆ bir öğretim yöntemidir" (Odabaş, 2003). Uzaktan 
eğitim tanımlarında vurgulanan nokta, eğitimi veren ve alan kişinin aynı mekânda olmak zorunda olmaması ve teknolojinin kullanılması şeklinde belirtilmiştir.

Uzaktan eğitimde özel ders planları ve özel öğretim teknikleri kullanılmaktadır. Öğretme faaliyeti normal öğrenmeye göre farklı ortamlarda oluşturulmaktadır. Planlı bir öğrenmenin gerçekleştirilmesinin amaçlandığı ve elektronik olan veya olmayan sistemlerin kullanıldığı bir öğrenme biçimidir (Biriş̧̧i, 2013). Farklı mekanlardaki öğrenci ve öğretmenin teknoloji ile bir araya getirildiği eğitim biçimi olduğu için standart eğitim modellerinden farklılık göstermektedir. Uzaktan eğitim ile bireyler okula veya işe gitmeden eğitim hayatlarını tamamlayabilmektedirler (Aslantaş, 2014). Uzaktan eğitimde eşzamanlı ve eşzamansız (senkron ve asenkron) olmak üzere iki model bulunmaktadır. Bunun dışında amaç ve kullanılan araçlara göre her iki grup kendi içinde etkileşimsiz ve etkileşimli olarak ayrılmaktadır. Etkileşimsiz uzaktan eğitimde iletişim tek yönlü olurken etkileşimli uzaktan eğitimde çift yönlü olmaktadır (Toker Gökçe, 2008; Aslantaş, 2014). Mektupla öğrenme şeklinde başlayan uzaktan eğitim teknolojinin gelişmesiyle birlikte web tabanlı platformlar üzerinden yeni formuyla ortaya çıkmıştır. Uzaktan eğitim yükseköğretim kurumlarının artan eğitim ihtiyaçlarına web tabanlı platformuyla destek olmaktadır. Fakat örgün eğitime alışmış ve onun gerekliliklerini yerine getiren öğretmen ve öğrenciler için web tabanlı uzaktan eğitim programları farklı sorunları da beraberinde getirmektedir. Uzaktan eğitimde gelişen teknolojiler hem zorlukları hem de avantajları beraberinde getirmektedir (Bilgiç \& Tüzün, 2015). Uzaktan eğitimin avantajları şu şekilde belirtilmiştir (Özer, 1990; Toker Gökçe, 2008; Kaya, 2002; Eygü \& Karaman, 2013; Özköse vd., 2013):

- Kitle eğitimini kolaylaştırma ve fırsat eşitliği sağlama

- Farklı eğitim seçeneklerinin öğrencilere sunulması

- Standart eğitim programları

- Maliyetin daha az olmas

- Öğrencinin daha serbest olması

- Bireysel ve bağımsız öğrenmeyi sağlama

- Öğrenme sorumluluğu oluşturma

- Belirli bir zamanda belirli bir yerde olma zorunluluğunun olmaması

- Daha hızlı geribildirim

- Sürekli öğrenmenin sağlanabilmesi

- Bireylerin kendi kendilerini geliştirebilmeleri

Uzaktan eğitimin yukarıda bahsedilen avantajlarının yanında bazı sınırlılıkları da vardır. Bunlar (Özer, 1990; Dinçer, 2006; Kaya, 2002; Özköse vd., 2013):

- Yüz yüze eğitim ve göz teması olmaması nedeniyle ilişki kurulmasının zor olması

- Sosyalleşme zorluğu

- Çalışan bireylerin dinlenmesi gereken zamanlarda eğitim alması

- Uygulamalı derslerden yeterince fayda sağlayamama

- Teknolojiye bağımlı olması

- Süreçte oluşan sorunların hemen çözümlenmemesi

- Kendi kendine öğrenme zorluğu yaşayan bireyler için planlama zorluğu

- Sayı fazla olduğu zaman oluşabilecek iletişim sorunları

- Alt yapı hazırlığındaki masraflar 
Literatürde hem öğrenciler hem de öğretmenlerin uzaktan eğitime yönelik tutumlarını belirlemeye yönelik çalışmalar mevcuttur. Fakat COVID-19 pandemisi nedeniyle örgün eğitimden uzaktan eğitime geçen öğrencilerin düşüncelerini belirlemeye yönelik sınırlı sayıda çalışmaya rastlanmıştır. Öz Ceviz ve diğerleri (2020) tarafından yapılan çalışmanın sonucunda öğrencilerin uzaktan eğitim yerine yüzyüze eğitimi tercih edecekleri tespit edilmiştir. Ağır (2007) tarafından yapılan çalışmada öğretmenlerin uzaktan eğitime yönelik tutum düzeyleri incelenmiştir. Öğretmenlerin uzaktan eğitime olan tutumlarının orta değere yakın ve olumlu olduğu bulunmuştur. Ateş ve Altun (2008) yaptıkları çalışmada araştırmaya katılan öğrencilerin uzaktan eğitime karşı tutumlarının kararsız seviyesine yakın olduğunu belirlemişlerdir. Ayrıca öğrencilerin algıladıkları bilgisayar kullanma becerilerinin de uzaktan eğitime yönelik tutumlarını olumlu etkilediği sonucuna ulaşılmıştır. Bilgiç ve Tüzün (2015) çalışmasında uzaktan eğitimin öğrenciler için pek çok sorun içerdiğini belirlemişlerdir. Biriş̧̧i’nin (2013) çalışmasında öğrencilerin uzaktan eğitime yönelik tutumlarının kararsız düzeyde olduğu tespit edilmiştir. Ders sırasında yaşanan teknik problemlerin iletişime zarar verdiği ve motive olmayı olumsuz etkilediği belirlenmiştir. Düzakın ve Yalçınkaya (2008) tarafından yapılan çalışmada öğretim elemanlarının elektronik hizmetlerin bazılarından yararlandıkları bazılarını ise kullanmadıkları tespit edilmiş̧ir. Eygü ve Karaman (2013) öğrencilerin almakta oldukları uzaktan eğitime yönelik memnuniyet algılarını incelemişlerdir. Fidan (2016) tarafından yapılan çalışmada ortak dersleri uzaktan eğitimle alan öğrencilerin uzaktan eğitime yönelik tutum puan ortalamasının diğer bölümlere göre düşük düzeyde olduğu belirlenmiştir. Belcheir ve Cucek (2002) tarafından yapılan çalışmanın sonucunda öğrencilerin uzaktan eğitimde zamandan ve mekândan bağımsız olma durumunu olumlu değerlendirdikleri ortaya çıkmıştır. Bunun dışında uzaktan eğitimin en olumsuz yanının ise daha fazla zamanı kapsaması ve öğrenme hatalarının daha fazla olduğu ifade edilmiştir. İbicioğlu ve Antalyalı (2005) uzaktan eğitimdeki başarıda bilgisayar imkânı, motivasyon ve algının oldukça önemli olduğunu tespit etmişlerdir. Kör ve diğerleri (2013) çalışmasında uzaktan eğitim derslerinde destekleyici ve etkileşime dayalı materyallerin kullanılmasının öğrencileri derse çekmek ve daha verimli eğitim için gerekli olduğunu belirlemişlerdir. Yalman ve Kutluca (2013) tarafından yapılan çalışmada öğrenciler uzaktan eğitimle ders verilmesi konusuna fikrim yok şeklinde cevap vermişlerdir. Öğrencilerin çoğunluğu uzaktan eğitim ile derslerinin işlenebileceğini düşünürken diğerleri ise derslerinin klasik yöntemlerle işlenebileceğini ifade etmişlerdir. Yılmaz ve Güven (2015) tarafından yapılan çalışmada öğrencilerin uzaktan eğitime yönelik metafor algıları araştırılmıştır. Araştırma sonucunda öğrencilerin daha çok uzaktan eğitimin verimsiz, sıkıcı, duygusuz bir eğitim şekli olduğunu düşündükleri belirlenmiştir. Yalman (2013) yaptı̆̆ 1 çalışmada öğrencilerin büyük oranının $(\% 76,57)$ uzaktan eğitim yönetim sistemiyle aldıkları eğitimden sonra eğitim gördükleri bölüme ait uzaktan eğitim seçenekleri bile olsa yine de yüz yüze eğitimi seçeceklerini belirlemiştir. Dick ve diğerleri (2001) ABD ve Avustralya'daki lisans ve yüksek lisans öğrencilerinin uzaktan eğitime yönelik tutumlarının kararsıza yakın seviyede olduğunu ve uzaktan eğitimi ikinci seçenek olarak gördüklerini belirlemiştir. İskenderoğlu ve diğerlerinin (2012) çalışmasında uzaktan eğitimde iletişim sorunlarının olduğu, öğrencilerin ve öğretmenlerin birbirlerini tanıyamadıkları tespit edilmiştir. Yapılan çalışmaların sonuçları incelendiğinde, genellikle öğrencilerin uzaktan eğitime bakış açılarının olumsuz ya da kararsız olduğu görülmektedir. Teknik problemler, motivasyon eksikliği, aynı ortamda olamama gibi nedenlerden dolayı ögrenciler uzaktan eğitimi olumsuz olarak değerlendirmişlerdir.

\section{YÖNTEM}

Çalışmanın bu bölümünde, İznik Meslek Yüksekokulu turist rehberliği bölümü öğrencilerinin COVID-19 pandemi sürecinde uzaktan eğitime ilişkin algılarını tespit etmeye yönelik keşifsel bir araştırma gerçekleştirilmiştir. Bu kapsamda bu bölümde Yıldırım ve Şimşek (2013: 91-97) nitel araştırma aşamaları dikkate alınarak araştırmanın nasıl tasarlandığı, araştırma yöntemi, örneklemi, veri toplama tekniği ve verilerin analizinde kullanılan yöntemler konularına yer verilmiştir.

Araştırmada kullanılan verilerin toplanabilmesi için gerekli olan etik kurul izin belgesi Bursa Uludağ Üniversitesi Etik Kurulu 03.07.2020 tarihi ve 19 karar numarası ile alınmıştır. 


\subsection{Araștırmanın Amacı}

Bu çalışmanın amac1; COVID-19 pandemi sürecinde turist rehberliği öğrencilerinin uzaktan eğitime olan bakış açılarını tespit etmektir. Bu amaçla belirlenen alt amaçlar aşağıda belirtilen sorulara cevap aramaktadır.

- Katılımcıların uzaktan eğitime olan değerlendirmeleri olumlu mu yoksa olumsuz mudur?

- Eğer katılımcilar uzaktan eğitim sürecini olumlu değerlendiriyorlarsa, bu süreç ile ilgili hangi konuları olumlu bulmaktadırlar?

- Eğer katılımcılar uzaktan eğitim sürecini olumsuz değerlendiriyorlarsa, bu süreç ile ilgili hangi hususları olumsuz bulmaktadırlar?

\subsection{Araştırmanın Önemi}

Çalışma COVID-19 pandemi sürecinde, uzaktan eğitimde yaşanan sıkıntıların neler olduğunun saptanması ve bu sıkıntıların nasıl firsata dönüsstürülebileceği konusunda önem arz etmektedir. Yapılan alanyazın taramasında bu doğrultuda yapılan kısıtlı çalışmaya rastlanmıştır.

\subsection{Araştırmanın Kısıtları}

Araştırma verilerinin toplanmasında mülakat tekniği kullanılmıştır. Mülakat tekniğinde yüz yüze mülakat yapılmak istenmiş ancak pandemi nedeni ile mülakatlar yüzyüze değil de online olarak gerçekleştirilmiştir. Bu durum bağlantı sorunları gibi teknik aksaklıklar nedeni ile derinlemesine mülakat yapılabilmesinde zaman kısıdı oluşturmuştur.

\subsection{Araştırmanın Evreni ve Örneklemi}

Araştırma sonuçlarının genellendiği, araştırma kapsamı içerisinde yer alan ortak özelliklere sahip birimler bütünü evren olarak tanımlanmaktadır (Ural \& Kılıç, 2011: 33). Özellikle sosyal bilimler alanında yapılan araştırmalarda, evrenin tamamına ulaşmak farklı sebeplerden (zaman ve kaynak yetersizliği gibi) mümkün olamamaktadır. Dolayısıyla bir araştırmada evrenin tamamı üzerinde çalışmak yerine, evrenden seçilen ve evreni temsil ettiği varsayılan örneklem üzerinde çalışma yapmak araştırmacılara birçok yönden kolaylık sağlamaktadır. Örneklem; belli bir ana kütleden (evren), o ana kütleyi temsil yeterliği olduğu kabul edilen, belli kurallara göre seçilmiş küçük bir örnek veya kütledir (Yazıcıŏlu \& Erdoğan, 2014: 32). Nitel araştırmalarda örneklem büyüklüğ̈̈nün dikkate alınmasında birkaç ilke vardır. Bu ilkeler araştırmanın odağı, veri miktarı ve kuramsal örneklemedir. $\mathrm{Bu}$ araştırmada kuramsal örneklem yaklaşımı dikkate alınmıştır. Bu yaklaşıma göre örneklem büyüklüğü, araştırma sorusunun yanıtı olabilecek kavramların ve süreçlerin tekrar etmeye başladığı anda (doyum noktası) yeterli büyüklüktedir (Yıldırım \& Şimşek, 2013:143). Bu kapsamda araştırmanın evrenini 2019-2020 bahar döneminde final sınavına katılan ve derslere devam eden Uludağ Üniversitesi İznik Meslek Yüksekokulu turist rehberliği öğrencileri oluşturmaktadır. Örneklem sayısı ise 52'dir ve evrenin \%59'una (52/88) ulaşılmıştır. Örneklem sayısının doyum noktasına ulaştığı ve yeterli olduğu kabul edilmektedir.

\subsection{Veri Toplama Yöntemi}

Saha araştırmasında yöntem olarak yarı yapılandırılmış mülakat tekniği ve tesadüfi olmayan örneklem yöntemi kullanılmıştır. Mülakat yöntemi nitel araştırmalarda en sık kullanılan veri toplama aracıdır. Bu yöntemle özellikle keşfe yönelik araştırmalarda ek soru sorulabilmekte daha ayrıntılı bilginin toplanması mümkün olabilmektedir. Araştırmada verilerin toplanmasına 16.07.2020 tarihinde başlanmış ve 30.07.2020 tarihinde veri toplama işlemi sona erdirilmiş̧ir. Görüşmeler sonrası mülakatların çözümlemesi yapılmış ve elde edilen veriler içerik analizine tabi tutulmuştur.

\subsection{Mülakat Formunun Hazırlanma Süreci}

Mülakat formunun hazırlanma sürecinde konuya ilişkin olarak ayrıntılı bir yazın araştırması yapılmıştır. Ayrıca soruların netleştirilmesinde 2 uzmanın görüşü alınmıştır. Araştırma sorularının belirlenmesinin ardından 10 kişiden oluşan bir gruba pilot çalışması yapılmış ve sorular revize edilmiştir. Böylelikle sorularda oluşabilecek sıkıcılık, karışıklık, kopukluk gibi problemlerin önüne geçilmesi mümkün olmuştur. 
Mülakat formunda katılımcıların COVID-19 pandemi sürecinde uygulanan uzaktan eğitime yönelik algılarını belirlemeye yönelik sorular yer almaktadır. İlgili sorular aşağıda belirtilmiştir.

- COVID-19 pandemi sürecinde biliyorsunuz ki eğitim uzaktan devam etmektedir. Eğitimin uzaktan devam ettiği bu süreci olumlu olma ya da olmama yönünden nasıl değerlendiriyorsunuz?

- Şayet bu pandemi sürecinde uzaktan eğitimi olumlu değerlendiriyorsanız, sizce uzaktan eğitimin olumlu yanları nelerdir? Şayet olumsuz değerlendiriyorsanız, uzaktan eğitim ile ilgili ne gibi sorunlar veya sıkıntılarla karşılaştınız?

\subsection{Verilerin Düzenlenmesi ve Analizi}

İçerik analizi, görüşme, gözlem veya dokümanların incelenmesi yolu ile elde edilen yazılı biçimdeki verilerin düzenlenmesi için başvurulan bir tekniktir. Bu teknikte veriler okuyucunun anlayabilmesine imkân verecek şekilde belirli süreçlerden geçirilerek sayılara ve rakamlara dökülür. $\mathrm{Bu}$ bağlamda, tekniğin amacı toplanan verilerden benzer olanları birbiri ile ilişkilendirerek belirli temalar altında toplamaktır. Bu bağlamda analiz dört aşamayı içermektedir. Birinci aşamada veriler kodlanır, ikinci aşamada temalar bulunur, üçüncü aşamada kodlar ve temalar düzenlenir ve son aşama olan dördüncü aşamada bulgular tanımlanır ve yorumlanır (Yıldırım \& Şimşek, 2013). İçerik analizinde güvenilirlik ve geçerliliğin sağlanması gerekmektedir. Güvenilirlik, öğelerin farklı gözlemciler tarafindan aynı kategoriye bağlanması ya da aynı gözlemci tarafindan farklı zamanlarda aynı kategori ile ilişkilendirilmesidir. Geçerlilik ise sosyal fenomeni tescil eden yorumlardır. İç geçerlilik araştırma sonuçlarına ulaşırken izlenen sürecin çalışılan gerçekliği ortaya çıkarmaktaki yeterlilikle ilgilidir (Coşkun vd., 2015: 325). Bu araştırmada güvenilirliğin sağlanması öğelerin farklı gözlemciler tarafından aynı kategoriye bağlanması ile gerçekleştirilmiştir. Bu bağlamda konusunda uzman iki akademisyenin görüşüne başvurulmuştur. Geçerlilikte ise iç geçerlilik kavramı üzerinde durulmuş ve elde edilen verilerin araştırma konusu ile ilgili olması, gerçek durumu yansıtması, anlamlı olması, yazında desteklenebilmesi gibi konulara cevap alınması sağlanmıştır. Bu çerçevede, elde edilen veriler benzerlik ilişkileri açısından incelenerek belirli kavramlar ve temalar içerisinde bir araya getirilmiş, frekans ve yüzde hesapları yapılarak okuyucunun anlayabileceği şekilde sunulmuştur. İlgili hesaplardaki minimal farklılıklar küsuratlardan kaynaklanmaktadır.

\section{ANALIZ VE BULGULAR}

Çalışmanın bu kısmında katılımcıların demografik özelliklerine ve COVID-19 pandemi sürecinde uzaktan eğitime ilişkin algılarına dair bulgular yer almaktadır. Bu bağlamda katılımcıların demografik özellikleri Tablo 1'de, COVID-19 pandemi sürecindeki uzaktan eğitim algıları ise Tablo 2, Tablo 3 ve Tablo 4'te belirtilmiştir.

Tablo 1: Katılımcıların Demografik Özellikleri

\begin{tabular}{lccccc}
\hline & Frekans & \% & Yaş & Frekans & \% \\
\hline Cinsiyet & & & & & \\
\hline Kadın & 28 & 52 & 18 Yaş alt & - & \\
\hline Erkek & 24 & 48 & $19-25$ & 48 & 82 \\
\hline Medeni Hal & & & $26-35$ & 4 & - \\
\hline Bekar & 51 & 98 & 36 ve üzeri & & \\
\hline Evli & 1 & 2 & & & \\
\hline
\end{tabular}

Tablo 1 incelendiğinde, katılımcıların \%52'sinin kadın, \%98'nin bekar ve \%92'nin 19-25 yaş aralığında olduğu görülmüştür. 
Tablo 2: Katılımcıların COVID-19 Pandemi Sürecinde Uzaktan Eğitime Olan Bakış Açılarına İlişkin Kodlar ve Temalar

\begin{tabular}{|c|c|c|c|c|c|}
\hline Temalar & Frekans & $\%$ & Kodlar & Frekans & $\%$ \\
\hline \multirow[b]{2}{*}{ 1.1. Olumsuz } & \multirow[b]{2}{*}{27} & \multirow[b]{2}{*}{52} & 1.1. Sikıntılı ve zorlu bir süreç & 27 & 52 \\
\hline & & & $\begin{array}{l}\text { 1.2. Planlama yapılırsa ve sistemsel sorunlar } \\
\text { giderilirse verim alınabilecek bir süreç }\end{array}$ & 15 & 29 \\
\hline $\begin{array}{l}\text { 1.2. Kismen Olumlu/Kismen } \\
\text { Olumsuz }\end{array}$ & 19 & 37 & $\begin{array}{l}\text { 2.1. Bu şartlarda yüz yüze eğitim kadar olmasa da } \\
\text { çözüm sunabilecek bir süreç }\end{array}$ & 4 & 8 \\
\hline 1.3. Olumlu & 6 & 11 & 3.1. Hastalık riskini önleyen bir süreç & 6 & 11 \\
\hline Toplam & & & & 52 & $\% 100$ \\
\hline
\end{tabular}

Tablo 2 incelendiğinde; katılımcıların $\% 11$ oranında az bir kısmı uzaktan eğitim sürecini olumlu olarak değerlendirmektedir. Geriye kalan \%52’lik kısım uzaktan eğitim sürecini olumsuz, $\% 37$ 'lik kısım ise kısmen olumlu/kısmen olumsuz olarak değerlendirmektedir. İlgili tema ve kodlara ilişkin katılımcıların bazı ifadeleri aşağıda belirtilmiştir;

K15. "Bana göre online eğitim olumlu değil. Böyle uzaktan eğitim isteseydim açık öğretim okurdum. Zaten sistemde düzgün değil."

K34. "Hiç yoktan iyidir, olumlu olduğunu düşünüyorum."

$\mathrm{K} 3$. "Bu süreç bence biz öğrenciler için hiç iyi olmadı evde olmamız sağlık açısından iyi olabilir ama asla okulda birebir alınan dersle öğretmenimin gözlerine bakarak dinlediğim dersle bir değil, sınav süreci dahil bir sürü eksiklik var."

K8. "Göz temasını kurmadan, eğitimin faydalı olacağını düşünmüyorum. Anlatırken o gözlerinin içine bakacaksın, karşılıklı bir etkileşim olacak."

K47. "Tabiki olumlu şu an yapılabilecek en iyi şey bu."

Tablo 3: Katılımcıların Pandemi Sürecinde Uzaktan Eğitim Sisteminin İşleyişine Dair Algıları

\begin{tabular}{|c|c|c|c|c|c|}
\hline Temalar & Frekans & $\%$ & Kodlar & Frekans & $\%$ \\
\hline \multirow{2}{*}{$\begin{array}{l}\text { 2.1. Olumlu } \\
\text { Yanlar }\end{array}$} & \multirow[t]{2}{*}{15} & \multirow[t]{2}{*}{18} & $\begin{array}{l}\text { Rahat konforlu ortam sunması (okula gidilmemesi, evlerde ve aile ile } \\
\text { olunmasi) }\end{array}$ & 8 & 9 \\
\hline & & & Kolay ulaş1labilir olması ve zamanın daha iyi kullanılabilmesi & 7 & 8 \\
\hline \multirow{5}{*}{$\begin{array}{l}2.2 . \\
\text { Olumsuz } \\
\text { Yanlar }\end{array}$} & \multirow{5}{*}{70} & \multirow{5}{*}{82} & $\begin{array}{l}\text { Yüz yüze veya birebir eğitimin ve/veya sınıf ortamının olmaması ve } \\
\text { eğitimin sadece çalışma notları ile yürümesi ve /veya ayrıntılı bilgi } \\
\text { edinememesi ve iletişim kurulamaması }\end{array}$ & 27 & 32 \\
\hline & & & Çalışma notlarının çok fazla, uzun olması ve /veya anlaşılır olmaması & 9 & 11 \\
\hline & & & $\begin{array}{l}\text { Sınavların sadece final ile kısıtlı kalması, vize sınavlarının yapılmaması } \\
\text { ve başarının etkin değerlendirilemediğinin düşünülmesi }\end{array}$ & 5 & 6 \\
\hline & & & $\begin{array}{l}\text { İnternet ve bağlantı gibi teknik sorunlar ve /veya bilgisayar internet } \\
\text { bağlantısı gibi teknik araç ve gerecin olmaması }\end{array}$ & 25 & 29 \\
\hline & & & Eğitimin planlı ve sistemli olmaması & 4 & 5 \\
\hline Toplam & & & & 85 & 100 \\
\hline
\end{tabular}

Tablo 3 incelendiğinde katılımcılar uzaktan eğitimin \%18 oranında olumlu yanını \%82 oranında olumsuz yanını dile getirmişlerdir. Görüldüğg̈ üzere katılımcıların çoğunluğu uzaktan eğitimin olumsuz yanlarını ifade etmektedirler. Söz konusu temalar olumsuz kodlar itibari ile incelendiğinde sıralama şu şekildedir: Yüz yüze veya birebir eğitimin ve/veya sınıf ortamının olmaması ve eğitimin sadece çalışma notları ile yürümesi ve /veya ayrıntılı bilgi edinememesi ve iletişim kurulamaması (\%32), internet ve bağlantı gibi teknik sorunlar ve /veya bilgisayar internet bağlantısı gibi teknik araç ve gerecin olmaması (\%29), çalışma notlarının çok fazla, uzun olması ve /veya anlaşılır olmaması (\%11), eğitimin planlı ve sistemli olmaması (\%5) şeklindedir. Olumlu kodlar ise şu şekilde sıralanmaktadır: Rahat konforlu ortam sunması (okula gidilmemesi, evlerde ve aile ile olunması) (\%9), kolay ulaşılabilir olması ve zamanın daha iyi kullanılabilmesi (\%8)'dir. İlgili tema ve kodlara ilişkin katılımcıların bazı ifadeleri aşağıda belirtilmiştir;

K9. "Tabii ki derslerin aksamaması güzel bir şey."

K4. "Olumlu çünkü en başta evinizdesiniz, rahatsızınız okul havası yok."

K10. "Zaman ve kolay ulaşılabilir." 
K20. "Kendi imkânlarımızla bir şeyler üretmeye yöneldik."

K18. "Bu süreç körelmeyi önlüyor."

K12. "Dönem boyunca derse ve sınava çalışmaya yönelik ayırdığım vakti şimdi yine dersler ile bağlantılı olan konularda daha derin araştırma yapmaya vakit buldum ve daha fazla kitap okumaya vakit ayırdım."

K35. "Daha rahat ve konforlu bir eğitim aldığımı düşünüyorum."

K2. "İnternet, sistem yavaşlı̆̆1."

K7: "İnternette sıkıntı olabiliyor elektrik kesilebiliyor sayfalarca karışık notu anlamak zor."

K11. "Bilgisayar ve internetin olmamas1."

K16. "Uyku düzenim bozuldu, programlar istediğim gibi gitmedi düzenim yok."

K29. "Ödevleri gönderirken bazen kabul etmiyordu birkaç kez denemek zorunda kaldım.”

K49. "Mesela evde bilgisayarı olmayan arkadaşlarım var. Uzaktan eğitime imkânı olmayan arkadaşlarım var, benim kardeşlerim evde bu süreçte ve ben kalabalıkta ders çalışamıyorum."

Tablo 4: Pandemi Sürecinde Uzaktan Eğitimin Katılımcılar Üzerindeki Etkilerini Ortaya Koyan Tema ve Kodlar

\begin{tabular}{|c|c|c|c|c|c|}
\hline Temalar & Frekans & $\%$ & Kodlar & Frekans & $\%$ \\
\hline \multirow{5}{*}{$\begin{array}{l}\text { 3.1. Olumlu } \\
\text { Etki }\end{array}$} & \multirow{5}{*}{28} & \multirow{5}{*}{33} & Dinleme, çalışma ve araştırmada etkinlik ve kişisel gelişim & 12 & 14 \\
\hline & & & Kendine zaman ayırabilme ve psikolojik rahatlama & 6 & 7 \\
\hline & & & Sağlığını riske atmama & 4 & 5 \\
\hline & & & Maddi tasarruf & 1 & 1 \\
\hline & & & Eğitimin devam etmesi & 5 & 6 \\
\hline \multirow{5}{*}{$\begin{array}{l}3.2 . \\
\text { Olumsuz } \\
\text { Etki }\end{array}$} & \multirow{5}{*}{56} & \multirow{5}{*}{67} & Dersi anlayamama ve öğrenememe & 13 & 15 \\
\hline & & & $\begin{array}{l}\text { Ders çalışmaya isteksizlik ve çalışmanın ertelenmesi; derse } \\
\text { odaklanamama, dersler için disipline olamama, zamanı iyi } \\
\text { kullanamama, derslerden ve okuldan uzaklaşma. }\end{array}$ & 26 & 31 \\
\hline & & & $\begin{array}{l}\text { Ekrandan çalışma, notları okumak zorunda kalış, özellikle gözlerde } \\
\text { ve belde beliren fiziki yorgunluk, uyuyamama. }\end{array}$ & 4 & 5 \\
\hline & & & $\begin{array}{l}\text { Teknolojiye bağımlılık, arkadaşlar ile olamama, sınıf ve okul } \\
\text { ortamının olamaması, eğlenememe, sosyalleşememe, aile içi } \\
\text { sorunlar ve psikolojik yorgunluk. }\end{array}$ & 10 & 12 \\
\hline & & & Eğitim sürecinin aksaması & 3 & 4 \\
\hline Toplam & & & & 84 & $\% 100$ \\
\hline
\end{tabular}

Tablo 4 incelendiğinde katılımcılar uzaktan eğitimin olumlu etkisini \%33 oranında, olumsuz etkisini ise \%67 oranında dile getirmişlerdir. Olumlu etkiler açısından kodlar incelendiğinde, ağırlıklı kodun "dinleme, çalışma, araştırmada etkinlik ve kişisel gelişim” (\%14) üzerinde toplandığı görülür. Diğer olumlu etki kodları ise sırası ile "kendine zaman ayırabilme ve psikolojik rahatlama (\%7)", "eğitimin devam etmesi (\%6)", "sağlığını riske atmama (\%5)", "maddi tasarruf (\%1)" şeklindedir. Olumsuz etkiler ise; ders çalışmaya isteksizlik ve çalışmanın ertelenmesi; derse odaklanamama, dersler için disipline olamama, zamanı iyi kullanamama, derslerden ve okuldan uzaklaşma (\%31), teknolojiye bağımlılık, arkadaşlar ile olamama, sınıf ve okul ortamının olamaması, eğlenememe, sosyalleşememe, aile içi sorunlar ve psikolojik yorgunluk (\%12), ekrandan çalışma, notları okumak zorunda kalış, özellikle gözlerde ve belde beliren fiziki yorgunluk, uyuyamama (\%5), eğitim sürecinin aksaması (\%4)'dır. İlgili tema ve kodlara ilişkin katılımcıların bazı ifadeleri aşağıda belirtilmiştir;

K17. "Böyle tehlikeli bir virüs gündemdeyken bizler evimizde en doğru şekilde eğitimimizi alıyoruz sağlı̆̆ımızdan olmuyoruz ne kadar verimli bilemem ama eğitimimize devam ediyoruz olumlu yanları bunlar benim için."

K6. "Psikolojik olarak yıprandım ailemle yaşamaya alışık olmadığımdan, hayatımı erteledim çünkü belli bir zaman kavramı yoktu artık." 
K21. "Hayır bence hiç de olumlu değil çünkü kendi evindesin en rahat olduğun yer. Evde olduğun için de hiçbir şekilde içimden kalkıp da notlara bakmak çalışmak gelmiyor açıkcası."

K44. "Evde bilgisayarım bulunmadığından sisteme telefonla giriş yapmak zorunda kaldım. Telefondan ders çalışmak her zaman benim için zor olmuştur. Gerek sistemin zorlukları gerek benim odaklanma problemlerim derken iyice uzaklaştırdı."

\section{SONUC VE ÖNERILER}

COVID-19 pandemisi 17 Nisan 2020 tarihi itibariyle dünya genelindeki 191 ülkede okulların kapatıldığ1 ve 1.724.657.870 öğrencinin bu süreçten etkilendiği küresel ve şiddeti yüksek bir krizdir. Bu kriz, diğer ülkelerde olduğu gibi Türkiye'deki yükseköğretim sürecini de etkilemiştir. Zira sosyal mesafenin yaratılması, özellikle genç nüfusun evde kalmasının sağlanarak bulaşıcılığın önlenmesi amac1 ile Türkiye'deki üniversitelerde eğitim-öğretim faaliyetlerinin, 23 Mart 2020 tarihinden itibaren uzaktan yürütme konusunda karar almıştır (Yılmaz vd., 2020: 3-11). Bu konuda karar alan üniversitelerden biri de Uludağ Üniversitesidir. Özellikle turizm eğitiminde görsel algının ön plana çıktığı turist rehberliği öğrencilerinin üzerinde yapılan bu çalışmada katılımcılar ağırlıklı olarak uzaktan eğitimin olumsuz olduğunu (\%52) ifade etmektedirler ve yine katılımcılar bu olumsuzluğun altındaki sebebi ağırlıklı olarak yüz yüze veya birebir eğitimin ve/veya sınıf ortamının olmaması ve eğitimin sadece çalışma notları ile yürümesi ve /veya ayrıntılı bilgi edinememesi ve iletişim kurulamamasını, internet ve bağlantı gibi teknik sorunlar (\%32) ve /veya bilgisayar internet bağlantısı gibi teknik araç ve gerecin olmaması (\%29), dersi anlayamama ve öğrenememe (\%15), çalışma notlarının çok fazla, uzun olması ve /veya anlaşı1ır olmamasını (\%11) dile getirmektedirler. Katılımcıların ağırlıklı bir kısmı ders çalışmaya isteksiz olduğunu ve çalışmasını sürekli ertelediğini, derslere odaklanamadığını, zamanını iyi kullanamadığını ve derslerden de okuldan da uzaklaştığını (\%31) ifade etmişlerdir. Ayrıca katılımcılar arkadaşları ile olamadıklarını, sınıf ve okul ortamını soluyamadıklarını, eğlenemediklerini, sosyalleşemeyip teknolojiye bağımlı hale geldiklerini ayrıca aile içi sorunlar yaşadıklarını ve bunlarında sonucunda psikolojik yorgunluk (\%12) yaşadıklarını ifade etmektedir.

Katılımcılar sistemin uzaktan eğitim sürecinin olumlu bir süreç olduğunu \%11'lik gibi az bir oranda belirtmişlerdir. Bu bağlamda katılımcılar uzaktan eğitimi rahat ve konforlu ortam sunan (\%9) ve kolay ulaşılabilir ve zamanın çok daha etkin kullanılmasına imkân veren (\%8) bir sistem olduğunu ifade etmişlerdir. Ayrıca katılımcılar bu süreçte her şeyi hazır bir şekilde edinemedikleri için daha iyi dinlemek, çalışmak ve araştırma yapmak durumunda kaldıklarını bu nedenle daha iyi öğrendiklerini (\%14) ve bu sayede kişisel gelişim gösterdiklerini dile getirmişlerdir. Yine katılımcılar (\%7) kendilerine zaman ayırabildiklerini ve psikolojik açıdan rahatlama imkânı bulduklarını (\%7) dile getirmekte ve eğitim süreçlerinin kesintiye uğramadığını (\%6) söylemektedirler. Görüldüğü üzere, eğer uzaktan eğitimde yaşanılan sıkıntılar giderilirse, uzaktan eğitim öğrencilerin çok daha verim alabileceği hatta tercih edebileceği bir süreç haline gelebilecektir. Bu bağlamda sürecin çok daha etkin yönetilebilmesi gerekmektedir. Bunun için çok yönlü dijital bir yapının kurulması gereklidir. Söz konusu yapı video ve konferans yolu ile eş zamanlı bir öğretimi mümkün kılmalı ve eğitim öğretim materyallerini sunma, paylaşma, ödev verme ve alma, tartışma, e-sınav yapma, öğrencilere geri bildirim sağlama, sürecin kaydını tutma, dersleri yönetme gibi amaçlara hizmet eder özellikte olmalıdır. Nitekim; Kör ve diğerleri (2013: 278) tarafindan yapılan çalışmada uzaktan eğitim derslerinde animasyon, video ve simülasyon gibi etkileşime dayalı materyallerin kullanılmasının öğrencileri konunun içine çektiği ve verilen eğitimi daha verimli hale getirdiği sonucuna ulaşmışlardır. Bir başka örnek ise Bozyel ve Doğantan (2020) tarafından yapılan "Uzaktan Eğitimde Deneyimsel Öğrenme Yöntemleri: Turizm Programları Üzerine Araştırma" adlı çalışmadır. Söz konusu çalışmada yazarlar uzaktan eğitim konseyi (ICDE) üyesi olan ve turizm alanında uzaktan eğitim veren 14 kuruluşun web sitelerini inceleyerek uzaktan eğitimde benimsenen yöntemleri ortaya koymuşlardır. İlgili çalışmada kuruluşların (konuk konuşmacılar, çevrimiçi video kitaplıkları, video görüntüleme, görsel malzeme, çevrimiçi kitaplıklar, stajlar, web konferansları, basılı materyal, web seminerleri, ortak çalışmalar, soru cevap forumlar, dijital malzeme, eşzamanlı platformlar, kinestetik öğrenme enstrümanları, ses materyali, simulatif saha gezileri, uygulamalı eğitim, çevrimiçi yüz yüze ders gibi) görsel, işitsel, okuma yazma ve kinetiksel olmak üzere dört öğrenme boyutuna hitap eden birçok yöntemi kullandıkları görülmüştür. Böylece kuruluşlar öğrenme stillerine göre öğrenme 
deneyimlerinin organizasyonu ile eğitim hedeflerine çok daha etkin ve çok daha verimli bir şekilde ulaşmaktadır (Bozyel \& Doğantan, 2020). Bu amaçla altyapısı zayıf üniversitelerce bu tarz yöntemleri esas alan ve birden fazla kullanıcının aynı platform veya iletişim kanalı aracılığı ile eş zamanlı öğrenmesini mümkün kılan Hangouts, Skype, Zoom vb. araçların kullanımının hayata geçirilmesi büyük önem arz etmektedir. Bu kapsamda özellikle gezme-görme etkinliklerinin pandemi öncesinde yoğun yürütüldüğü turist rehberliği öğrencilerine söz konusu dijital eğitim sistemi (animasyonlar, videolar, simülasyonlar gibi) öğretim araçları ile desteklenebilmelidir. Sistem öğrencinin uzaktan eğitim sürecine aktif olarak katılabilmesini sağlayacak şekilde tasarlanmalı, öğretim kaynakları öğrencinin ilgisini çekecek şekilde hazırlanmalı ve kullanılmalı, içeriğin zorluk derecesi ve formatı öğrenciye uygun bir şekilde hazırlanmaası gerektiği düşünülmektedir. Yine internete erişimde yeterli altyapıya sahip olmayan öğrencilere yönelik olarak (bilgisayar temini) teknik donanımın sağlanabilmesi amacı ile desteklerin sağlanmasının faydalı olacağı düşünülmektedir. Bu çerçevede hükümet, Yükseköğretim kurulları ve kuruluşlar arasında güçlü bir iş birliğinin sağlanması ve hem öğretmenler hem öğrencilere yönelik olarak çevrimiçi eğitimde karşılaşlan sorunların çözümüne yönelik hem de psikolojik sorunların çözümüne yönelik destek hizmetlerin düzenlenmesi gerektiği düşünülmektedir.

Etik Beyan: Bu araştırmada kullanılan verilerin toplanabilmesi için gerekli olan etik kurul izin belgesi Bursa Uludağ Üniversitesi Etik Kurulu 03.07.2020 tarihi ve 19 karar numarası ile alınmıstır. Aksi bir durumun tespiti halinde AKAD Dergisinin hiçbir sorumluluğu olmayıp, tüm sorumluluk çalışmanin yazar (lar) ına aittir.

Yazar Katkı Beyant:1. Yazarın katkı oranı \%55, 2. Yazarın katkı oranı ise \%45. 'dir.

Çıkar Beyanı: Yazarlar arasında çıkar çatışması yoktur.

Ethics Statement: The ethics committee permission document required for the collection of data used in this study was obtained at the date of 03.07.2020 and with the decision number 19 of Bursa Uludağ University Ethics Committee. In case of detection of a contrary situation, AKAD Journal has no responsibility and all responsibility belongs to the author(s) of the study.

Author Contributions Statement: The contribution rate of the author is 55\%, the contribution rate of the 2 nd author is $45 \%$.

Conflict of Interest: There is no conflict of interest between the authors.

\section{KAYNAKÇA}

Ağır, F. (2007). Özel okullarda ve devlet okullarında çalışan ilköğretim ögretmenlerinin uzaktan eğitime karşı tutumlarının belirlenmesi [Yayınlanmamış Yüksek Lisans Tezi, Balıkesir

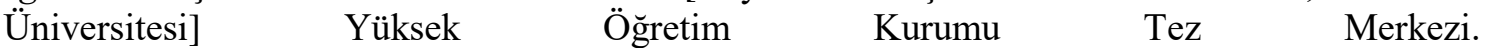
https://tez.yok.gov.tr/UlusalTezMerkezi/tezSorguSonucYeni.jsp

Akdemir, Ö. (2011). Yükseköğretimimizde uzaktan eğitim. Yükseköğretim ve Bilim Dergisi, 1(2), 6971. https://doi.org/10.5961/jhes.2011.011

Al, U., \& Madran, O. (2004). Web tabanlı uzaktan eğitim sistemleri: Sahip olmas1 gereken özellikler ve standartlar. Bilgi Dünyasl, 5(2), 259-271. https://doi.org/10.15612/BD.2004.491

Aslantaş, T. (2014). Uzaktan eğitim, uzaktan eğitim teknolojileri ve Türkiye'de bir uygulama. 1-62. https://www.tankutaslantas.com/wp-content/uploads/2014/04/Uzaktan-E\%C4\%9Fitim-UzaktanE\%C4\%9Fitim-Teknolojileri-ve-T\%C3\%BCrkiyede-bir-Uygulama.pdf

Ateş, A., \& Altun, E. (2008). Bilgisayar öğretmeni adaylarının uzaktan eğitime yönelik tutumlarının çeşitli değişkenler açısından incelenmesi. Gazi Ĕgitim Fakültesi Dergisi, 28(3), 125-145. https://dergipark.org.tr/en/download/article-file/77108

Baturay, M., \& Bay, Ö. F. (2009). Uzaktan öğretimi tercih eden öğrencilerin demografik özellikleri. Dicle Üniversitesi Ziya Gökalp Eğitim Fakültesi Dergisi, (13), 17-26. https://dergipark.org.tr/en/download/article-file/787109

Belcheir, M. J., \& Cucek, M. (2002). Faculty perceptions of teaching distance education courses. Boise State Üniversitesi. https://files.eric.ed.gov/fulltext/ED480925.pdf 
Bilgiç, G. H., \& Tüzün, H. (2015). Yükseköğretim kurumları web tabanlı uzaktan eğitim programlarında yaşanan sorunlar. $\quad$ AUAd, 1(3), 26-50. https://dergipark.org.tr/en/download/article-file/35550

Birişçi, S. (2013). Video konferans tabanlı uzaktan eğitime ilişkin öğrenci tutumları ve görüşleri. Journal of Instructional Technologies Teacher Education,2(1), 24-40. https://dergipark.org.tr/en/download/article-file/231299

Bozkurt, A. (2017). Türkiye'de uzaktan eğitimin dünü, bugünü ve yarını. AUAd, 3(2), 85-124. https://dergipark.org.tr/en/download/article-file/403827

Bozyel D., \& Doğantan E. (2020). Experimental learning methods in distance education: Research on tourism programs. V. Krystev, M. S. Dinu, R. Efe, \& E. Atasoy (Eds.), Advances in social science research (pp. 486-499). St. Klıment Ohrıdsk1 University Press.

Coşkun R., Altunışık R., Bayraktoroğlu S., \& Yıldırım, E. (2015). Sosyal bilimlerde araştırma yöntemleri SPSS uygulamall. Sakarya Yayıncılık.

Çoban, S. (2013). Uzaktan ve teknoloji destekli eğitimin gelişimi. XVI. Türkiye'de İnternet Konferans1 Bildiri Kitab1.

Demir, E. (2014). Uzaktan eğitime genel bir bakış. Dumlupınar Üniversitesi Sosyal Bilimler Dergisi, 39, 203-212. https://dergipark.org.tr/en/download/article-file/55935

Deperlioğlu, Ö., \& Yıldırım R. (2009). Mesleki eğitimin uzaktan eğitim ile desteklenmesi ve örnek uygulama. AKÜ Fen Bilimleri Dergisi, 01, 61-70. https://dergipark.org.tr/en/download/article$\underline{\text { file/ } 18692}$

Dick, G. N., Case, T. L., \& Burns, O. M. (2001). Adopting distance education what do the students think?. Proceeding of the International Academy for Informational Management, 213-225. https://files.eric.ed.gov/fulltext/ED474103.pdf

Dinçer, S. (2006). Bilgisayar destekli eğitim ve uzaktan eğitime genel bir bakış. Akademik Bilgi ve İletişim Konferansı, Pamukkale Üniversitesi.

Düzakın, E., \& Yalçınkaya, S. (2008). Web tabanlı uzaktan eğitim sistemi ve Çukurova üniversitesi ögretim elemanlarının yatkınlıkları. Journal of the Cukurova University Institute of Social Sciences, 17(1), 225-244. https://dergipark.org.tr/en/download/article-file/50421

Ekici, G. (2003). Uzaktan eğitim ortamlarının seçiminde öğrencilerin öğrenme stillerinin önemi. Hacettepe Üniversitesi Eğitim Fakültesi Dergisi, 24, 48-55. https://dergipark.org.tr/en/download/article-file/87825

Erturgut, R. (2008). İnternet temelli uzaktan eğitimin örgütsel, sosyal, pedagojik ve teknolojik bileşenleri. International Journal of Informatics Technologies, 1(2), 79-85. https://dergipark.org.tr/en/download/article-file/75244

Eygü, H., \& Karaman, S. (2013). Uzaktan eğitim öğrencilerinin memnuniyet algıları üzerine bir araştırma. Sosyal Bilimler, 3(1), 36-59. https://dergipark.org.tr/en/download/article-file/181058

Fidan, M. (2016). Uzaktan eğitim öğrencilerinin uzaktan eğitime yönelik tutumları ve epistemolojik inançları. Hacettepe Üniversitesi Eğitim Fakültesi Dergisi, 31(3), 536-550. https://doi.org/10.16986/HUJE.2016016666

Horzum, M. B., Özkaya, M., Demirci, M., \& Alpaslan, M. (2013). Türkçe uzaktan eğitim araştırmalarının incelenmesi. İnönü Üniversitesi Eğitim Fakültesi Dergisi, 14(2), 79-100. https://dergipark.org.tr/en/download/article-file/92208

İbicioğlu, H., \& Antalyalı, Ö. L. (2005). Uzaktan eğitimin başarısında imkân algı motivasyon ve etkileşim faktörlerinin etkileri: Karşılaştırmalı bir uygulama. Çukurova Üniversitesi Sosyal Bilimler Enstitüsü Dergisi, 14(2), 325-338. https://dergipark.org.tr/en/download/article$\underline{\text { file } / 50240}$ 
İskenderoğlu, M., İskenderoğlu, T. A., \& Palanc1, M. (2012). Opinion of teaching staff in distance education systems, regarding the assessment and evaluation process. Procedia-Social and Behavioral Sciences, 46, 4661-4665. https://doi.org/10.1016/j.sbspro.2012.06.314

İşman, A. (2011). Uzaktan eğitim. (Geliştirilmiş 4. Baskı). Pegem Akademi.

Kaya, Z. (2002). Uzaktan eğitim. Pegem A Yayıncılık.

Kırık, A. M. (2014). Uzaktan eğitimin tarihsel gelişimi ve Türkiye'deki durumu. Marmara İletişim Dergisi, 21, 73-94. https://doi.org/10.17829/midr.20142110299

Kör, H., Çataloğlu, E., \& Erbay, H. (2013). Uzaktan ve örgün eğitimin öğrenci başarısı üzerine etkisinin araştırılması. Gaziantep University Journal of Social Sciences, 12(2), 267-279. http://repository.bilkent.edu.tr/bitstream/handle/11693/52110/Investigation of the effects of d istance_education_and_formal_education_into_student_success.pdf?sequence=1\&isAllowed=y

Odabaş, H. (2003). İnternet tabanlı uzaktan eğitim ve bilgi ve belge yönetimi. Türk Kütüphaneciliği, 17(1), 22-36. http://tk.org.tr/index.php/TK/article/view/167/162

Öz Ceviz, N., Tektaş N., Basmacı G., \& Tektaş, M. (2020). Covid-19 pandemi sürecinde üniversite öğrencilerinin uzaktan eğitime bakış1: Türkiye örneği. Ulakbilge, 52, 1322-1335. https://doi.org/10.7816/ulakbilge-08-54-06

Özbay, Ö. (2015). Dünyada ve Türkiye'de uzaktan eğitimin güncel durumu. Uluslararası Eğitim Bilimleri Dergisi, (5), 376-394. https://dergipark.org.tr/tr/download/article-file/562769

Özer, B. (1990). Uzaktan eğitim sisteminin evrensel yapısı. Kurgu Dergisi, 8, 569-594. https://dergipark.org.tr/en/download/article-file/1503899

Özköse, H., Arı, S., \& Çakır, Ö. (2013). Uzaktan eğitim süreci için SWOT analizi. Middle Eastern \& African Journal of Educational Research, 5, 41-55. https://www.researchgate.net/publication/308983166_Uzaktan_Egitim_Sureci_icin_SWOT_An $\underline{\text { alizi }}$

Toker Gökçe, A. (2008). Küreselleşme sürecinde uzaktan eğitim. Dicle Üniversitesi Ziya Gökalp Eğitim Fakültesi Dergisi, (11), 1-12. https://dergipark.org.tr/en/download/article-file/787151

Ural, A., \& Kılıç, İ. (2011). Bilimsel araştırma süreci ve SPSS ile veri analizi. Detay Yayıncılık.

Yalman, M. (2013). Eğitim fakültesi öğrencilerinin bilgisayar destekli uzaktan eğitim sistemi (moodle) memnuniyet düzeyleri. Electronic Turkish Studies, 8(8), 1395-1406. https://web.s.ebscohost.com/ehost/pdfviewer/pdfviewer?vid=0\&sid=0a1383c8-1b20-470ca657-cf9bab08edfb\%40redis

Yalman, M., \& Kutluca, T. (2013). Matematik öğretmeni adaylarının bölüm dersleri için kullanılan uzaktan eğitim sistemi hakkındaki yaklaşımları. Dicle University Journal of Ziya Gokalp Education Faculty, 21, 197-203. https://dergipark.org.tr/en/download/article-file/786877

Yazıcıoğlu, Y., \& Erdoğan, S. (2014). SPSS uygulamalı bilimsel araştırma yöntemleri. Detay Yayıncilik.

Yıldırım A., \& Şimşek H. (2013). Sosyal bilimlerde nitel araştırma yöntemleri. Seçkin Yayınları.

Yılmaz, E., Mutlu H., Güner, B., Doğanay G., \& Yılmaz, D. (2020). Veri algisina göre pandemi dönemi uzaktan eğitim sürecinin niteliği. Palet Yayınları.

Yılmaz, G. K., \& Güven, B. (2015). Öğretmen adaylarının uzaktan eğitime yönelik algılarının metaforlar yoluyla belirlenmesi. Turkish Journal of Computer and Mathematics Education, 6(2), 299-322. https://doi.org/10.16949/turcomat.75936 